\title{
TYPES OF POWER IN INTERTEXTUALITY: SIR KEN ROBINSON'S TED TALK 'DO SCHOOLS KILL CREATIVITY?' AS A SAMPLE
}

\author{
Araxi Krikor Thomas Sarkisian and Alya M. H. Ahmed Al-Rubai' \\ Dept. of Translation, College of Languages, University of Duhok, Kurdistan Region-Iraq
}

(Received: January 12, 2020; Accepted for Publication: July 24, 2020)

\begin{abstract}
ABSRACT
This study attempted to investigate the use of intertextuality as a source of power in a TED talk sample, viz., Sir Ken Robinson's 'Do Schools Kill Creativity?' within the framework of Critical Discourse Analysis (CDA). This paper followed a qualitative paradigm in analyzing the sample data. Accordingly, an eclectic model was devised, integrating Gee's (2014a, 2014b) model of intertextual analysis and French and Raven's (1959) model of the bases of social psychological power. The application of this model to the selected data has yielded some conclusions, the most salient of which is that intertextuality is important in TED talks as it is used to show implicit meanings to exercise two types of power: expert power and referent power. Accordingly, it is recommended to consider power relations and the exercise of power when conducting any intertextual analysis within the framework of CDA.
\end{abstract}

KEYWORDS: Discourse, Intertextuality, Power, TED

\section{INTRODUCTION}

I ntertextuality is one of the most important concepts in contemporary CDA (Fairclough, 1992). It refers to the use of one text within another, whether in the form of a quote, a reference, or an adaptation of a grammatical structure, or style (Gee, 2011). Power, on the other hand, is one of the most researched topics in CDA and it is expressed through language by the use of accessible forms of language (Van Dijk, 2008). While intertextuality and power have been investigated separately, only a few people hinted about their correlation, including Fairclough (1992) who notices that people can reproduce power through intertextuality, where the person speaking is among a few who have access to that source of power. Briggs and Bauman (1992), similarly, believe that examining intertextuality highlights the examination of ideology and power relations because discourse has historical, social, and political associations with previous discourses. However, no studies, to the best of the researchers' knowledge, have been conducted about the types of power exercised through the intertextual references within TED talks. Hence, this study will try to fill this gap in the literature.

This study aims to investigate the role of intertextuality in producing different types of power in a TED talk sample, vis., Sir Ken Robinson's 'Do Schools Kill Creativity?'. It aims to investigate how the intertextual structures are used to reflect and influence the ideologies of the presenter and the audience respectively. Accordingly, this study will try to answer the following questions: 1) what intertextual forms are used in this TED talk? 2) what types of power are exercised through intertextuality and how do they influence the social ideologies of the audience? and 3) how does the presenter position himself and his cause in relation to these texts?

Sir Ken Robinson's TED talk was chosen as the data for this study because for a few years now, it has been the most watched video on www.ted.com, with more than 62 million views until September, 2019 (Robinson, 2006). Accordingly, this study limits its investigation to spoken discourse and does not take into consideration the stage setting or the audience reactions to this talk. Moreover, to achieve the aims of the study and answer the research questions in regards to this data sample, an eclectic model was devised by combining Gee's (2014a; 2014b) model of intertextuality with French and Raven's (1959) model of the bases of social power. Overall, this study will hopefully be of value to language teachers and people who are interested in social studies and online discourse. It will hopefully contribute to the development of the topic within the framework of CDA.

araxi.sarkisian@yahoo.com 


\section{INTERTEXTUALITY: ORIGINS AND DEVELOPMENT}

Intertextuality is a relatively recent term that is marked as a turning point in literary criticism and linguistics (Allen, 2000). The French critic Julia Kristeva (1967, as cited in Allen) coined the term in her essays about the works of the Russian literary theorist M. M. Bakhtin, whose books and articles influenced many disciplines, including literary criticism and linguistics. Intertextuality originated within the framework of literary criticism, which might be why Carstens (1999) refers to it as the least linguistic notion. In her essay 'Word, Dialogue, and Novel' (1986, as cited by Keep, McLaughlin, \& Parmar, 2000), Kristeva said that "any text is constructed of a mosaic of quotations; any text is the absorption and transformation of another" (ibid., p. 66). With this claim, Kristeva broke the tradition of literary criticism where critics depended on the author's identity to interpret the writings of that author, and instead, she shifted the focus on the relationship of the literary text with other texts and literary structures (Keep et al., 2000). This statement was based on Roland Barthes' notion of 'the death of the author' where he accentuated, within literary criticism and semiotics, that the interpretation of any text relies on the reader's own experiences and knowledge of language and other texts (ibid.). Thus, intertextuality widens the perspective of text interpretation and makes it more personal.

Allen (2000) claims that intertextuality actually originated in the writings of the Swiss linguist Ferdinand De Saussure. He explains that the Saussurean linguistics promoted intertextuality through its interest in linguistic signs, where Saussure viewed a sign as a coin with two sides; a signified (i.e. a mental image) and a signifier (i.e. a sound image), meaning that a linguistic sign in not just a word that refers to a specific object, but a combination of a signified and a signifier. Thus, the meaning of linguistic signs is not referential in nature, but rather relational, meaning that signs do not have meaning by themselves, but only when in a semantic relation with another sign (Allen, 2000). Allen concluded that Saussure's sign theory introduced the relational nature of meaning that has ultimately led to the study of the relational nature of texts, i.e. intertextuality.

Saussure's (1974, as cited in Allen, 2000) sign theory led to the existence of Semiology: the study of signs and their meaning within the structure of a text, and this, in turn, led to the formation of the structuralism movement in the 1950 s in which everything was viewed as consisting of structures. However, this movement did not focus on the relationship between language and people but on how meaning was constructed and layered, therefore a new movement was formed in the 1960s called post-structuralism in which the focus shifted from the linguistic sign to utterances which can be defined as the unit of speech that consists of at least a spoken or written word that contains the human element and the social aspects of language (Baker and Ellege, 2011; Allen, 2000). Post-structuralists state that linguistic signs have social meanings which are "constantly negotiated and consented through language and discourse" (Baxter, 2003, as cited in Baker \& Ellege, 2011, p. 98). In other words, utterances (texts in CDA) are interpreted according to the specific social contexts in which they occur (Allen, 2000). It was during the post-structuralist movement that Kristeva introduced Bakhtin's work and the concept of intertextuality to the world (ibid.).

Bakhtin (1986, as cited in Fairclough, 1992) believes that the meaning of texts is entirely dependent on the intertextual relations they have with previous texts in addition to the reaction they will get from future texts. He states that each text is seen as a link between previous texts and future texts; he referred to this phenomenon as the "chain of speech communication" (Fairclough, 1992, p. 270). Both Kristeva and Bakhtin emphasize that intertextuality does not just show the connection between texts, but the cultural background and social beliefs as well (Allen, 2000). Kristeva (1986, as cited in Fairclough, 1992) says that Bakhtin distinguished two dimensions of intertextuality which she calls vertical and horizontal "relations of intertextual space" (p. 271). Vertical intertextual relations are found in texts that refer to other texts that are not in that same context, i.e. they determine the position of discourse within history and society (Fairclough, 1992; Riggs \& Bauman, 1992). Horizontal intertextual relations, on the other hand, stand for the dialogical relationships of a text that preceded or followed it in that same context; as in the different turns of a conversation (Fairclough, 1992; Allen, 2000). From another point of view, Fairclough (1992) says that French discourse analysts like Authier-Revuz and Maingueneau draw a distinction between two types of 
intertextuality, depending on its form in the text; namely manifest intertextuality and constitutive intertextuality. He says that manifest intertextuality appears explicitly in the text in that it is marked, for example, by quotation marks or preceded by a reporting verb; whereas, constitutive intertextuality is unmarked and is usually integrated within the text's structure and style as in paraphrasing other texts and putting them in one's own words. There are various forms of intertextuality and different (critical) discourse analysts use different terms to refer to them. Gee (2014b), for example, states that intertextuality can appear in the form of quotations, reported speech, allusion and reference, the integration of different social languages (discourses); and the use of specific grammatical structures; whilst Fairclough (1992) said that intertextuality can appear in the form of discourse representation (explicitly marked texts, i.e. via quotation marks or reporting verbs), presupposition, and interdiscursivity (constitutive intertextuality). Whatever the terms are, intertextual analysis is not like the descriptive linguistics analysis; rather it is interpretive in nature in that it relies on linguistic devices to analyze texts historically and socially (ibid.).

In a relatively recent study, Gordon (2009) studied the role of intertextuality in meaning making within family interactions. She asked a family of three people to audio record a week of their lives. After analyzing the data, she found that intertextuality does not just refer back to older texts, but it creates a family framework in which an interaction can allude or refer back to a previous interaction that is unique within that family. This shows that intertextuality acts as a semantic and contextual link between the new text and previous ones that are exclusive to a certain social group.

Intertextuality can be examined from different perspectives, including literature (through literary criticism) and linguistics (through text linguistics and CDA). In text linguistics, Halliday and Hasan (1976) refer to intertextuality as one of the seven standards of textuality; besides cohesion, coherence, intentionality, acceptability, informativity, and situationality. They say that these standards make texts communicative and that if any of them was not met, the text will not be communicative and it will be considered a nontext. Halliday and Hasan define intertextuality as the way in which one text relies on a previous one in order to be fully understood. In CDA, on the other hand, intertextuality provides a wider perspective of the historical and social context of texts (Baker \& Ellege, 2011). What makes intertextuality important in CDA is that through its study, one can look at how language changes and how cultural and social changes affect that process (Fairclough, 1992). Fairclough (1992) says that intertextuality can change existing discourses and restructure different social and cultural conventions. However, he stated that the ability to produce new texts is bound by power relations, i.e. it is controlled by social structures in which the speaker/ writer is among a few who have access to a source of power, in this case, the intertext that is used to create a new text. This points out the main intertextuality limitation in that it can complicate the process of interpreting a text (Fairclough, 1992). The linguist and literary critic Michael Riffaterre points out that in order for people to interpret a text containing intertextuality; they should have the linguistic and literary competence necessary for that, otherwise, the meaning of the text will be lost (Allan, 2000).

Briggs and Bauman (1992) study generic intertextuality which focused on intertextual relations within a literary genre or across genres. Genre is usually defined as the classification of texts into specific discourse categories (Baker \& Ellege, 2011). Genres, in general, possess powerful historical relations in that the discourse of a certain genre is produced and interpreted according to its relationship with previous discourses from the same genre (Briggs \& Bauman, 1992). Genres also have "social, ideological, and political-economic" (p. 147) associations, thus, according to Bakhtin (1986, as cited in Briggs \& Bauman, 1992), genres have "ideological mediated connections" (p. 145) that are determined by the social group's practices, as well as their age, gender, profession, and social status. Consequently, intertextuality determines the "form, function, discourse structure and meaning" (p. 147) of texts, the producer's identity, and the ideologies the producer is introducing within the text (Briggs \& Bauman, 1992). Briggs and Bauman (1992) believe that discourse is a "recontextualization" (p.148) of previous discourses, in other words, discourse or parts of it are taken from their initial context and subsequently used in a new and different context. This process within a specific genre and a specific interaction highlights the power relations as well as the identity of the 
interlocutors in that the producer of the text has the "authority needed to decontextualize discourse that bears these historical and social connections and to recontextualize it in the current discursive setting" (p. 148). In other words, the producer practices power through textual authority by connecting their discourse to previous discourses. This is one of the reasons that make the current study interesting in that it examines the types of power and power relations through the intertextual references of a relatively new genre, i.e. TED talks.

\section{MODELS OF INTERTEXTUAL ANALYSIS IN CDA}

There are a few models of intertextual analysis in CDA. Fairclough (1995), for example, presents a three-dimensional model for intertextual analysis in his book Media Discourses (1995). The three dimensions include discourse representation analysis, generic analysis of discourse types, as well as the analysis of discourses in a text (ibid.). Fairclough's model was made to analyze intertextuality in the news, with a focus on the discourse representation dimension since it is a major element in the news that shows what "newsworthy people have said" (Wang, 2006, p. 136). Gee (2011), on the other hand, uses intertextuality as a tool to analyze any discourse critically. His model studies the different forms and styles in which intertextuality is presented in texts because there are a lot of ways in which a text can quote, allude to, or refer to another. The first way is through direct quotations, which are usually marked with single, rather than double quotation marks in spoken discourse, as in "It's funny that Bob said 'I'll never give up' then gave up" (Gee, 2014, p. 171). The second way is through indirect quotations which, on the other hand, do not use quotation marks and are known as indirect speech, as in "It's funny that Bob said he would never give up but gave up" (ibid.). Such structures use reporting verbs like she said, he claimed, they stated (Fairclough, 1992). People from different social and educational backgrounds use this type of intertextuality (Bauman, 2004). They use it in everyday interactions to report what others have said earlier, whereas scholars use this technique to allude to published texts within their writings (Fairclough, 1992; Bauman, 2004).

Another way to refer to other texts is by alluding to them, as in Those two brothers are like Cain and Abel (Gee, 2014). By mentioning Cain and Abel, one can understand that the brothers in the new text are not on good terms. A more informal allusion is that of Tom and Jerry from the famous animated cartoons. This is when the interpretation of the text through the intertext becomes complicated. If the readers or hearers of these texts do not know who Cain and Abel are, as well as Tom and Jerry for that matter, they would not be able to understand the intended meaning of the speaker/ writer. Hence, intertextuality depends on the shared knowledge of the speaker/ writer and the hearer/ reader (Trask, 2007).

Translation is considered one of the types of intertextuality in that the translated text refers to the original text (Bauman, 2004). Nevertheless, it faces the same problem as allusion in that different languages have their own interpretations of social and cultural contexts (Fairclough, 1992). Translation can, therefore, be viewed as a complex form of intertextuality because, in a way, the translator will interpret the previous text to match the social and cultural contexts of the target language.

People may use words and phrases from a specific profession or social language (genre) in another (Gee, 2014). Hence, business vocabulary can be used in a sentence like Let's invest our time in learning Japanese which may be said among siblings and friends in everyday interaction. Cross-referencing one social language in another is another type of intertextuality (Gee, 2014). It is often referred to as "the juxtaposition" (p. 112) of different social languages (Gee, 2011). Furthermore, certain grammatical structures can be mirrored to produce new texts (Gee, 2014). For instance, one can use the Shakespearean style of questioning something as in his 'To be or not to be, that is the question', the opening line of Hamlet, in saying sentences like To eat or not to eat, or To sleep or not to sleep. This shows the intertextuality in reference to style, when a text "echoes" (p. 172) another (Gee, 2011). Even though the two models mentioned above use different terminologies, they use similar intertextual analysis tools. Both look at implicit and explicit intertextual forms and consider grammatical devices in the process of analysis, in addition to comparing the text to different text genres. Moreover, they both agree that intertextuality is a matter of understanding and interpreting a text from one's own perspective and knowledge of the world. 
Gee's (2014a, 2014b) model of intertextual analysis is within the framework of CDA. Gee's (2011, 2014a) approach regards discourse as a form of social communication that is mainly social, ideological and political, and thus, shaped by power relations. Since people produce and interpret discourse according to certain conventions, i.e. ideologies, discourse is political (Gee, 2011). If someone wants to be considered appropriate and normal, they follow certain conventions because they view them as "social goods" (ibid. , p.5). Gee defines social goods as the things "some people in a society want and value" ( p. 5). He said that some people do not view certain conventions as social goods, and thus, want to resist and/ or change them. Accordingly, language is political, in the sense that it determines how social goods are distributed in a society, i.e. "who gets what in terms of money, status, power, and acceptance" (ibid., p. 7).

Gee (2011) states that through language use, one can construct seven things, namely, "seven areas of reality" (p. 17). He calls them the seven building tasks, saying that they are called 'tasks' because discourse analysts analyze discourses by asking various questions about these seven areas. They are: significance, practices, identities, relationships, politics, connections, and sign systems and knowledge. The first building task, significance, refers to the ability of making things of greater or lesser significance through language use (Gee, 2011; 2014a). The second building task, practices (or activities), refers to institutional and cultural actions that people engage in through language use (ibid.). Gee (2011) claims that people can take on different identities, the third building task, in different contexts. According to the type of identity built, Gee said that we build formal or informal social relationships, the fourth building task, with individuals or groups of people. Politics, the fifth building task, refers to the distribution of social goods that, in turn, investigate power relations in a society (Gee, 2011). The sixth building task, connection, refers to the connections language users make between various concepts (ibid.). Gee said that some things are not essentially connected with others in certain contexts, however, language can connect them. The last building task, sign systems and knowledge, denotes the ability of making some sign systems (languages, dialects, etc.) or forms of knowledge privileged in a specific situation (Gee, 2011).
Along the seven building tasks mentioned above, Gee (2011) presents various tools of analysis called "tools of inquiry" (p. 28). The tools of inquiry are "thinking devices" (p. 60) that guide the analysis of specific samples of discourse and the seven building tasks presented in them (ibid.). In his book, How to do Discourse Analysis, Gee (2014b) offers 28 tools of inquiry, stating that discourse analysts can use as many of them in their analysis as is necessary for their research questions and aims. However; only eight of these tools are relevant for this study, including intertextuality and the seven tools that correspond with the seven building tasks. These include:

1. The significance building tool: Gee said that one of the grammatical devices used to increase or decrease the significance of things is via foregrounding and backgrounding information. The former means mentioning information in the main clause of a sentence to make it more significant in that context; whereas, the latter means mentioning information in a subordinate clause to make it less significant in that time and place.

2. The activities building tool: Gee suggested looking at the social, cultural and institutional significance of activities and what is taken to be a standard or of value in a specific community. Therefore, he recommended analyzing the sequence of actions performed and accomplished in these activities in order to discover what is regular, routine, and standard in a specific context and what is not.

3. The identities building tool: Gee suggested examining how people express themselves and their identities in different situations via discourse. To do so, analysts should consider the individual's vocabulary set, language style (formal or informal/ everyday language or specialist), and the structural patterns used in a specific context.

4. The relationship building tool: to analyze the relationship between the interlocutors, Gee said that the analysts should consider the speaker's use of modal verbs, as well as the type of the sentences that are used to build, sustain or change the social relationships in certain contexts.

5. The politics building task: language is used to give or deny social goods via the use of "face needs" (p. 125). 'Face' is the way in which people want to be treated and privileged in different socio-cultural settings. Gee mentioned that there are three types of face needs: positive 
face, negative face, and face-threatening. Positive face is when people want to be more involved in social interactions and activities, negative face is when people value privacy and stand against others' interference with their personal activities, whereas face-threatening refers to people's over-involvement through the act of requesting and demanding. The latter puts the social goods of the interlocutors at risk.

6. The connections building tool: the grammatical device that is used to connect ideas and sentences in discourse is cohesion.

7. The sign systems and knowledge building tool: according to Gee, various sign systems represent various world knowledge views and beliefs that people take to be of more value than the other sign systems and knowledge. To figure what is valued more than others, the analysts should investigate the structural patterns and vocabulary sets.

In order to do an intertextual analysis within the framework of CDA, Gee (2014a) offered the following questions:

1. How is intertextuality being used to build relevance or significance?

2. How is intertextuality being used to enact a practice?

3. How is intertextuality being used to enact or depict identities?

4. How is intertextuality being used to build and sustain social relations?

5. How is intertextuality being used to create, distribute, or withhold social goods (i.e. things that people find acceptable or valuable)?

6. How is intertextuality being used to make things and people connected or relevant to each other or irrelevant to or disconnected from each other?

7. How is intertextuality being used to privilege or disprivilege different sign systems and ways of knowing? (p. 121)

Gee's (2014a, 2014b) intertextuality model is one of the adopted models used in the analysis of the current data sample. It combines the linguistic proper approaches of discourse analysis and the socio-cultural approaches of CDA. It does not focus on an intended area of application and that makes it easily adaptable. The other model is French and Raven's (1959) model of the bases of power and it looks at the power relations between the producer and the interpreter of the text.

\section{POWER IN CDA}

The exercise of power and power relations are at the center of almost all the theories of CDA. Critical Discourse Analysis is one of the trends in the study of language in use where discourse samples from the real world are collected and examined from different social contexts in order to unveil the hidden ideologies that lead to the exercise of power in different social communities (Ahmadvand, 2011; Heller, 2001, as cited in Baxter, 2010). In fact, CDA is critical in the sense that it focuses on the relationship between discourse, as well as social and political relations (Krings et al., 1973, as cited in Wodak, 2001).

One of the notions that influenced the development of CDA is Gramsci's (1971, as cited in Tenorio, 2011) notion of hegemony, which stands for the theory that power can be exercised and domination can be attained not only by exploitation, coercion, and oppression, but also by consensus and complicity that result from acts of persuasion. In other words, power can be exercised and maintained in a social group or community not just via physical and economic coercion, but by the ideologies that are implanted within the different social hierarchies (Baker \& Ellege, 2011). This complicates the process of defining power since it can be perceived as influence, persuasion, manipulation, and domination.

The concept of power can refer to various things, one of which is the physical power people use to defend themselves or force their will on others. Talbot (1998, as cited in Baker and Ellege, 2011) says that in modern society, power does not lie in the physical power of people, but in their social and political status. This widens the view from discourse to the power that resides in the social and political hierarchy, where a person who is at the top of a social or political hierarchy can control the others, their environment, and their ideologies via discourse (Baker \& Ellege, 2011). Therefore, Weber (1982, as quoted in Baker and Ellege, 2011) defines power as "the probability that one actor within a social relationship will be in a position to carry out his own will despite resistance, regardless of the basis on which this probability rests" (p. 28). This definition introduces the two sides of the social practices; power and resistance, meaning that when a person's attempt to control or change the opinions and beliefs of the other members of 
their social group is met with resistance. Moreover, Fairclough (1989) states that power is not permanently owned by one person or social group for power is only obtained and exercised in the case of social struggles, and that power can shift from one person or social group to another. In other words, one person may have power for a while, but may lose it later on.

Critical discourse analysts study how power is created and maintained via discourse in a social group (Baker \& Ellege, 2011). They focus on how different discourses are produced, distributed, as well as consumed in a social group in different social events (Fairclough, 1995, as cited in Baker and Ellege, 2011). Gee (2014a) believes that discourse represents the knowledge of the people, how they view the world, their dominant thoughts, ideological assumptions, and speech patterns in specific contexts while participating in a specific social practice. Fairclough (1989), on the other hand, says that discourse is "a place where relationships of power are actually exercised and enacted" (p. 43). He said that according to Habermas (1984) power in discourse is the way in which a person with power controls and limits the involvement of people with no power in social interaction. He stated that the powerful person can exercise control over three things, namely the content of the interaction, the social relations and "the subject position [identity] people can carry" (p. 46) within that interaction.

Discourse in modern day society involves producers and interpreters who are not in the same context, such as in the discourse of mass media (i.e. radio, television, and newspapers) (Fairclough, 1989). This applies to online videos as well, like the TED talk investigated in this study. This type of discourse can be described as one-sided since the interpreter cannot reply to the producer of the text immediately, which is usually done in the form of online comments. In such a discourse, Fairclough (1989) says that the producers of the text exercise power through controlling and restricting the content of their speech/ writing, the relationship they want to establish with their listeners/ readers, in addition to the subject position they want to put their audience in.

According to Foucault, there is no universal form of the exercise of power and that there are many forms of power in every social community, including military, legal, administrative, as well as economic power (MsHoul \& Grace, 2002). However, he classifies power into two types: sovereign power and disciplinary power (Foucault, 1979, as cited in Baker \& Ellege, 2011). He says that sovereign power is exercised by the sovereign or state where a person with a superior status has the power to punish, compel, or execute a person; whereas, he refers to disciplinary power as persuading people to submit by obtaining their consent. Foucault concluded that the latter seemed a much more convenient method of control and that is why it is the main type of power exercised within the western societies. This emphasizes the role discourse plays in exercising and maintaining power in that discourse is the medium that creates and carries ideologies, and ideologies, in turn, form the basis of power. However, power does not always come from discourse alone, but through the social and historical hierarchy, gender, age, education, and so on (Fairclough, 1989, Briggs \& Bauman, 1992).

\section{TYPES OF POWER}

French and Raven (1959) describe power as universal, complex, and usually disguised within social groups. They studied power, which they view as influence, from a social psychological point of view, saying that the study of power focuses on the social psychological relationship of the interlocutors, in other words, the behaviour of the person who exercises power and the reaction of the person who is at the other end of the interaction. They claim that the main purpose of their study and attempt to classify the types of power was to study the social and political changes and reactions they stimulate. Thus, they examine the power that is exercised within an interaction between two people or groups; O: the person or group who exercises the power, and $\mathrm{P}$, the recipient of O's influence. French and Raven introduced five types of power which people commonly use to influence others in their social groups: namely, reward, coercive, legitimate, referent, and expert power. They named the types of power according to the basis of that power.

French and Raven (1959) define reward power as the power exercised by a person who has the ability to reward P. They claim that the range of this power can be determined by the value of the reward as viewed by $\mathrm{P}$, and thus, this type of power can only be exercised when $\mathrm{P}$ complies to O's influence in order to get the reward they desire. However, if the reward was 
not of a great significance to $\mathrm{P}$, this power cannot be exercised and $\mathrm{O}$ is not obliged to accept the influence of $\mathrm{O}$ (ibid.). French and Raven (1959) state that "the utilization of actual rewards (instead of promises) by $\mathrm{O}$ will tend over time to increase the attraction of $\mathrm{P}$ toward $\mathrm{O}$ and therefore the referent power of $\mathrm{O}$ over $\mathrm{P}^{\prime \prime}$ (p. 322). This, in turn, will make P comply to O's influence without resistance and with the opinion that $\mathrm{O}$ has a legitimate right to give rewards (ibid.). Referent power, on the other hand, is the power that resides in "the identification of $\mathrm{P}$ with $\mathrm{O}^{\prime \prime}$ (p. 325), in other words, $\mathrm{P}$ is highly attracted to $\mathrm{O}$ and $\mathrm{O}$ 's ideologies and status because $\mathrm{P}$ views $\mathrm{O}$ as a "prestigeful person or group" (ibid., p. 325). Thus, according to French and Raven, O possesses "the ability to influence $\mathrm{P}$, even though P may be unaware" (p. 325) of this type of power.

French and Raven (1959) define coercive power as the power exercised by a person who has the ability to punish or withhold reward from $\mathrm{P}$ if $\mathrm{P}$ did not conform to O's influence. This type of power can be perceived as having the opposite effects of Reward power in that it "will decrease the attraction" (p. 323) of $\mathrm{P}$ to $\mathrm{O}$ and will increase P's resistance (ibid.). Accordingly, this type of power has a negative effect on the relationship between $\mathrm{O} / \mathrm{P}$ in that $\mathrm{P}$ 's actions will be dependent on O's ability to punish them. Legitimate power, on the other hand, is the power that is exercised by a person who has a "legitimate right to influence $\mathrm{P}$ and that $\mathrm{P}$ has the obligation to accept this influence" (French \& Raven, 1959, p. 323). This type of power is usually agreed upon by the different members of social groups in that $\mathrm{P}$ has to accept the influence of $\mathrm{O}-$ who is usually of a higher status in that social group- as legitimate in order for this power to be exercised (ibid.). The fifth and last of French and Raven's types of power is expert power which can be defined as the power expressed by a person who possesses professional knowledge as well as expertise in a specific field, usually more than P's knowledge and expertise in that field. Out of all these types of power, French and Raven stated that referent power has the strongest range, although if $\mathrm{P}$ wants to be associated with $\mathrm{O}$ to blend in O's social group and avoid being criticized, then that is a case of coercive power, whereas if $\mathrm{P}$ wants to be associated with $\mathrm{O}$ to be praised and admired, then it is a case of reward power.
Another classification of power types was presented by Weber (1978, as cited in AlBarwary, 2014) who classified power to coercion and authority, where coercion referred to the illegal exercise of power and authority referred to the legal one. Weber used the word 'domination' instead of 'power' and focused his study on authority. He said that authority is legitimized on three grounds: rational, traditional, and charismatic. Each of these grounds has a corresponding power type; viz. rational legal authority, traditional authority, and charismatic authority (ibid.). Weber (1978, as cited in Al- Barwary, 2014) defined rational authority as the authority that is based on "the legality of enacted rules" (p. 215) and the legal right of the authoritative person to control and command others. $\mathrm{He}$ defined traditional authority as "the legitimacy of those exercising authority under" (p. 215) tradition, whereas he defined charismatic authority as the power that is based on an individual's character which is viewed as exemplary and heroic (ibid.). Both taxonomies can be used together to create an overall model of examining the types of power in certain discourses. In a contrastive study, AlBarwary (2014) examined the exercise of power in the political discourse of two inaugural speeches. She analyzed her data using an eclectic model combining Fariclough's (1989) CDA model, Weber's (1987) social psychological classification of power relations, as well as French and Raven's (1959) social psychological types of power relations. She concluded that the most recurring types of power were authoritative, charismatic, and legitimate power. This study examines the types of power in a TED talk, which in not political in nature. That is why French and Raven's (1959) model of the types of power is chosen as part of the eclectic model devised for this study.

\section{TED TALKS}

TED Talks are popular conference videos from the TED organization that millions of people watch online every day. TED is a nonprofit organization that holds biannual conferences in Monterey, California, to present new findings and ideas in various topics (TED, n.d.(a)). TED organization's initial purpose in 1984 was to share ideas in the field of technology, entertainment and design (henceforth TED) through conferences that every curious person in the world could apply to 
attend (TED, n.d.(b); Theunissen, 2014). Currently, they have the same purpose but they cover many more topics than the original three, like architecture, history, and mental health (Ludewig, 2017). Most of the conference content and presentations are available worldwide through their website 'www.ted.com' and their YouTube channel 'TED' (TED, n.d.(b)).

The week-long conferences consist of more than 50 talks that last 18 minutes or less, in addition to beginning and end-of-day gatherings where people can share their ideas across fields and genres (TED, n.d.(a); n.d.(b)). TED Talks do not follow specific language and presentation patterns because, according to Anderson (2016), one of the reasons why people like attending TED conferences or watching TED talks online is because of their freshness and uniqueness. However, Romanelli, Cain, and McNamara (2014, as cited in Ludewig, 2017) state that TED talks are structured and that the presenters are told how to structure their talk. Denskus and Esser (2015, as cited in Ludewig, 2017), on the other hand, state that the presenters structure their talks in a logical way that resembles various sorts of entertainment like the element of surprise in theatre and storytelling. Anderson (2016) says that the presentations are curated, supervised and rehearsed. Nevertheless, the presenters are advised to simplify any complex scientific concepts in order to spread the ideas to a wider audience (TED, n.d.c). This makes TED talks very interesting to research.

Ludewig (2017) states that when TED contents surfaced online in 2006, it started "a new phase of distribution" (p. 2) in that it acquired a secondary audience. She says that the conference attendants are the "primary audience" (p. 2) whereas the secondary ones are those who watch the TED talks online. Nonetheless, not all the talks of the conference are available online since TED curates all of its online contents, hence, the primary audience have the privilege of accessing all of the conference talks. Even though the secondary audiences are in fact online viewers, the word 'audience' will be used throughout the paper to refer to them.

Although a lot of scholars agreed to call TED talks a genre on their own, only a few scholars actually examined its features as a genre. As far as TED talks are concerned, D'avanzo (2015, as cited in Ludewig, 2017) views them as a new genre that is built through the "hyberdization" (p. 281) of various different genres. In addition, Ludewig (2017) states that TED is "an emergent discourse genre" (p. 2); explaining that when someone refers to TED talks, people will understand the reference because it is a widely "recognizable label"(p.2).

The TED talk genre has three different generic components, the first of which is "a sales pitch" (p. 4) where the presenters, in a way or another, sell ideas whilst promoting their findings (Ludewig, 2017). Secondly, TED talks have an educational aspect where the presenters stand on a stage in front of an audience and inform them about a certain topic. Thirdly, TED talks resemble memoirs since the presenters are talking about their own experiences and the circumstances that led to the discovery of the idea they are sharing in their talks (ibid.). In other words, TED talks show the presenters' biographies, the journey to discovering their ideas, as well as their ability to communicate with the audience through their enthusiastic and emotional storytelling techniques. That is why one can view TED talks as a unique genre that merges the objective professional and educational elements with the subjective, private and storytelling elements.

\section{METHOD}

This study follows a qualitative paradigm in analyzing the collected data sample. The data sample studied here is Sir Ken Robinson's TED talk 'Do Schools Kill Creativity?' which was performed in February, 2006.

An eclectic model was devised by combining Gee's (2014 a, 2014b) model of intertextuality with French and Raven's (1959) model for the types of power in order to investigate how the speaker relied on other texts in making his text, the reasons he used them, the types of power exercised through them, as well as how he positioned himself in relation to these texts within his statement. The analysis consists of three parts, which in turn, contain several steps (as mentioned above):

Part one: different forms of intertextuality will be taken out (according to Gee (2014a; 2014b) above) in addition to their reference or origins, to be analyzed in part two of the model.

Part two: Gee's questions about the seven building tasks will be answered using the seven tools of inquiry that correspond with them in order to analyze the different forms of intertextuality taken out in part one. 
Part three: the intertextual analysis from part two will be used to determine the types of power expressed through intertextuality.

The examples taken from the TED talk in the analysis and discussion sections will be numbered. The findings of the analysis will then be studied and compared to the literature review in order to come up with conclusions about the data sample of this study.

\section{DATA ANALYSIS}

Sir Ken Robinson's TED talk is about the negative effects of the current educational system in general. He said that the main purpose of his talk is to criticize the shortcomings of the education system and its negative effects on people's creativity. He elucidated his argument with plenty of examples from his life and expertise as an educator and curriculum designer.

\section{Part one (intertextual forms and reference):}

This talk contains different forms of intertextuality. When it comes to explicit/ manifest intertexts, this talk has many quotes and reported speech, and most of them were uttered during narratives of past events and conversations. The speaker quoted a few of the most commonly uttered sentences in a school environment; like: (1) "Must try harder", (2)"And put the pencil down", (3) "Stop speaking like that", and (4) "It's confusing everybody." Robinson narrated a story about his four-year-old son's participation in a school play called Nativity II- the part where the three kings gave baby Jesus gold, frankincense and myrrhand he said that when the boys playing kings put the boxes they were carrying in front of the baby, (5) "the first one said, "I bring you gold.", and the second boy said, "I bring you myrrh.", and the third one said, "Frank sent this."". The reporting clause with these five implicit intertexts was "said", which the speaker used to refer to the act of communication. According to Quirk et al. (1985), direct speech is primarily used to report the exact words said in a previous discourse.

Reported speech, on the other hand, was used to introduce other people's texts. Robinson told the story of how people are really interested in education but they do not like spending time with educators because of their past study experience, saying that if they met them at, for example, a dinner party, they would say sentences like (6) "Oh my God. Why me?" and
(7) "My one night out all week". In this narrative, Robinson uses the reported speech; (8) "you say you work in education, you can see the blood run from their face". Quirk et al. (1985) explained that reported speech consists of a paraphrase or a summary of what others have said, written, or done.

According to Anderson (2016), Robinson's opening sentences (9) "Good morning, how are you? It's been great, hasn't it? I've been blown away by the whole thing. In fact, I am leaving." refer to the TED talks that were performed before his, saying that Robinson's talk was one of the last ones in the last day of the conference. This implicit intertext shows the advantage the primary audience of the conference have over the secondary audience in understanding the intertexts that refer to other talks within that same conference.

There are many instances of allusion in the talk, allusions to other people, beliefs and organizations. For example, the speaker compared education to religion and money, which is a cross-reference that proves that education is as important as religion. In another example, the speaker alluded to the famous Spanish artist Picasso, who is famous for his creative painting skills, and quoted his words by saying that (10) "he said that "all children are born artists. The problem is to remain an artist as we grow"." He also referenced Shakespeare, a well-known British artist, saying that if Shakespeare was told to "put the pencil down" or "stop speaking like that" he would not have been that famous or significant. Robinson also referenced Sirena Huang, an 11 year old violinist at the time and a TED presenter in the same conference as Robinson, as an example of creativity and talent. Another reference was to the actor and director Mel Gibson and his work on the movie The Passion of the Christ. Each of these references has its own significance and purpose within this talk. They will be analyzed in the second part of the analysis.

Even though the talk is in a formal everyday language, it contains intertexts from different social languages/ genres like education, art, and religion. Intertexts 1 to 4 are from education, example 5 references religion and a children's play, and the reference to Shakespeare, Picasso, and Huang are related to different forms of art.

As far as translation is concerned, it is hard to determine whether or not Robinson translated any part of his speech from another language. As for the use of certain grammatical structures, 
some of the intertexts were in the imperative form as in (2) "put the pencil down," and (3) "Stop speaking like that". According to Quirk et al. (1985), one of the uses of imperatives is to show authority. The significance of using all of these different forms of intertextuality and the intertextual analysis of these texts will be in part two of the analysis where Gee's (2014a, 2014b) questions of the seven building tasks will be answered to complete the intertextual analysis part of the model.

Part two (intertexts and the seven building tasks):

1. Significance: From a structural point of view, the intertexts in this talk were all foregrounded, which increased their significance and role in meaning making. Robinson used intertextuality to refer to other texts, discourses, and social practices and compared them with the practice and concept of education to show its significance. He denoted that education is important by comparing it to money and religion using a simile, but he critiqued its application within schools as a criminal act in that it "kill[s] creativity". The personification of the inanimate 'schools' gave significance and seriousness to the matter at hand. To clarify his point of view and show the significance of the effect of the school environment on the students' creativity, Robinson quoted some of the sentences used in schools by educators to control their students and make them submit to their will, as in (1) "Must try harder," (2) "And put the pencil down," (3) "Stop speaking like that," and (4) "It's confusing everybody", asking the audience to imagine Shakespeare's father saying them to Shakespeare. Moreover, throughout the talk, Robinson referenced famous figures like Picasso, Sirena Huang, and Mel Gibson in order to convince the audience that the educational system should not just focus on the basic topics of science, math, and languages, but rather on more versatile and creative fields like music, drawing, and acting since they have a significant effect on the economy and popularity of a country. Furthermore, each intertextual form used in this talk shows the significance of the intertexts. Quotations were used to report the exact words said within a narrative, which has the ability to carry the audience into that narrative, whereas cross-referencing different social languages shows the knowledge of the speaker.

2. Practices: The intertext (8) "you say you work in education, you can see the blood run from their faces" shows how people have a negative perspective about the education system. By referring to that, Robinson is attempting to change the perspective of his audience about education and how schools have a negative impact on the students' education and future. He relied on personal expertise and used narratives and references to present a new practice, that of resisting the routine of the educational system. This activity can be viewed as irregular because educators usually defend the school systems and view them as a necessity in building the children's future. Instead, he referenced Sirena Huang and Picasso who worked on their artistic skills without any help from the educational system.

3. Identities: This TED talk shows the identity of the presenter as a person who wants to change the educational system and a person who is sympathetic towards students. Through intertextuality, Robinson shows the identity of the educators as people who control the classroom whose aims are to make the students obey orders and act similarly; as in (3) "Stop speaking like that." Accordingly, he takes on the identity of an educator who is more interested in stimulating the creativity and critical thinking of students than making them sit in a classroom where everyone is silenced and controlled.

In addition, through referencing the previous TED talks in that same conference in his opening sentences (9) "Good morning, how are you? It's been great, hasn't it? I've been blown away by the whole thing. In fact, I'm leaving," the presenter enacted the identity of a knowledgeable person who knew what the audience experienced before his talk as well as the significance the audience gave to the previous talks. This identity is recurrent throughout the talk where the presenter used intertexts from different professions like art, religion, music, and, of course, education.

4. Social relations According to the identities motioned above, Robinson is distancing himself from the other educators. Through the use of intertextuality, specifically narrating past events in the vernacular/ everyday language, Robinson made the audience relate to his stories, and in turn, to his point of view about education. With the story of how people do not like spending time with educators, Robinson showed the audience/viewers that he is a person who is usually rejected by society because of his occupation, but in doing so, he connected 
himself to the audience/ viewers either in a relatable manner or a sympathetic one.

5. Politics Robinson is denying the education system of social goods and is challenging the ideology that it exists to educate children and make them more creative. He criticized the way educators exercise power in the classroom where the students have to do what they are told by quoting the commonly used sentences in the classroom, as "Put the pencil down," and "Stop speaking like that." However, through referencing famous artists like Shakespeare and Picasso and an eleven-year-old violinist who presented a TED talk before him, Robinson gave social goods to talent and self-development.

6. Connections: Robinson connects education with religion and money to show the significance of education. He also connected the education system to the future of the students, saying that the education system tries to teach the student how to live and work after more than 16 years of studying where many things will not be the same, saying "creativity now is as important in education as literacy." This stresses that the education system should evolve and focus on helping students not just be literate, but creative as well, since no one knows what the future holds. In addition, referencing artists like Shakespeare and Picasso was used to connect personal creativity to the lack of the emphasis on its importance in the school environment.

7. Sign systems and knowledge: Robinson acknowledged that everyone is aware of how important education is, but he disprivileged the education system because it does not encourage creativity. The use of the imperative sentences; as in "Must try harder" and "put the pencil down," prove that educators aim to control the students and put them all in the same mind set, instead of encouraging creativity and individuality.

\section{Part three (types of power):}

Since TED talks are one-sided talks, it is difficult for the presenter to exercise reward, coercive, or legitimate power because he does not have the ability or right to reward, punish, or influence the audience. Yet, through the use of intertextuality, the presenter can point to the exercise of power and either use it as an expert to influence the audience, or as a reference to confirm his point of view.

The most prominent power relation Robinson referred to via intertextuality is the studentteacher relationship, where the teacher exercises all five types of power. The school quotes in the emperative form, vis. "Must try harder," "and put the pencil down," and "Stop speaking like that," are used as an example of the teachers' exercise of legitimate power that enables them to control the classroom. Through their control of the classroom, they exercise two types of power: reward power and coercive power, where they reward the students who comply and punish those who do not. Through this intertext, Robinson exercised expert power and claimed that students need to be treated as individuals. To further prove his point, he used another intertext that showed people's reaction towards educators because of their bad experiences in the education system, viz. (8) "you say you work in education, you can see the blood run from their face."

Most of the intertexts express referent power because Robinson as $\mathrm{P}$ is influenced by them and is using them to influence his audience in return. These intertexts include the opening sentences of the talk, the play quote, and alluding to artists like Picasso, Shakespeare, and Sirena. Surprisingly, one can view Robinson's exercise of referent power and expert power as his way of exercising legitimate power because he believes that it is his legitimate right as an educator to tell the audience, through expertise and reference, that the problem he is referring to is worth solving.

\section{DISCUSSION}

Overall, the presenter used intertextuality to exercise power and influence the viewers to change the ideologies they have about the education system. He communicated his ideas via the use of language in general and intertextuality in particular. This data sample contains various forms of intertextuality which convey hidden meanings and ideologies. There were explicit intertexts, i.e. quotations, reported speech, and allusion; in addition to paraphrases of previous discourses and the use of specific grammatical forms like the imperative form. This indicates that intertextuality is an important device in TED talks because through intertextuality one can refer and allude to previous texts in order to give meaning to the new one.

This data contained vertical and horizontal intertextual relations, as it referred to previous texts from different contexts as well as other texts within that same TED conference, for example, the beginning sentences of this talk and 
alluding to Sirena Huang, who presented a TED talk before Robinson. However, the presenter directly referred to Sirena's TED talk, and it was easy to interpret. Yet his opening sentences that alluded to the talks that preceded this one were a bit hard to interpret because Robinson did not directly refer to them and the online audience are not in the immediate context of the conference to be able to interpret that intertext. In a sense, this is similar to Gordon's (2009) conclusion in that intertextuality created a social frame in which a text can allude or refer back to previous texts that are unique within that social group, i.e. the attendants of the TED conference

In connecting one text with many others, the presenter built the seven areas of reality mentioned above. Since language is shaped by power relations, and power in discourse is how a person controls the presentation, the presenter of this TED talk exercised power by controlling the intertexts he, intentionally or unintentionally, presented. And through the exercise of expert power, the presenter determined his relationship with his viewers, where he is the source of knowledge and experience and the viewers are the people whose educational ideologies he wants to change.

The two types of social psychological power exercised in the talk are expert power and referent power. Though, as mentioned above, the presenter might be exercising legitimate power because he might think that it is his right to tell people how to react about education. This is different from Al-Barwary's (2014) findings about the types of power in political discourse, where legitimate power was accompanied with charismatic, authoritative and reward power. In comparison, the presenter of the TED talk does not have any direct authoritative and legitimate relations with the viewers; consequently, legitimate power could not be exercised through this TED talk.

\section{CONCLUSIONS}

This study relied on an eclectic model to identify the relationship between intertextuality and the exercise of different types of power in the spoken discourse of TED talks. Accordingly, it has come up with the following conclusions about this data sample:

1. The relationship between intertextuality and power is crucial because the exercise of power depends on how language with all of its seven standards is used to influence people.
2. Intertextuality functions as a source of power by using previous texts to give meaning to the new one.

3. Two types of social psychological power were exercised in this TED talk through the use of intertextuality: expert power and referent power. Yet, intertextuality was used to refer back to all five types of power exercised through previous texts.

4. Intertextuality is an essential concept in TED talks because TED talks present ideas through the use of narratives of past events that primarily led to the formation of these ideas and the production of the new text.

5. Different forms of intertextuality were used in this TED talk to build various areas of reality, the most used ones were quoting and referencing.

6. Horizontal and vertical intertextual relations occurred in this sample. The horizontal ones are harder to interpret if the presenter did not directly state them.

7. This study also found that the presenter relied on his professional, cultural, and social ideologies and referenced them using intertextuality in order to influence the audience and change their ideologies.

Intertextuality and the exercise of power are interrelated. Accordingly, critical discourse analysts are recommended to include power analysis in the analysis of intertextuality, as Briggs and Bauman (1992) stated, intertextual analysis accentuated the analysis of power because all discourses are connected historically, socially, and politically. Even though TED talks are audio-visual talks, this study limited its scope to the spoken discourse. Further research could include multimodal analysis which analyzes the stage setting, body language, PowerPoint presentations, audience reactions, and the written comment threads on the TED talk platform.

\section{REFERENCES}

Ahmadvand, M. (2011). Critical Discourse Analysis: An introduction to major approaches. Jurnal Ilmiah Dinamik, Bahasa dan Budaya (Indonesian Journal of Linguistics and Cultural Studies), 5 (1), 82-90. Retrieved from https://www.unisbank.ac.id/ojs/index.php/fbib 1/article/view/382/pdf [Accessed: 13 January, 2019].

Al-Barwary, H. A. Y. (2014). Power in Political Discourse: A Contrastive Analysis between 
English and Kurdish Political Speeches (MA thesis, University of Duhok, Duhok, Iraq).

Allen, G. (2000). Intertextuality. London: Routledge.

Anderson, C. (2016). TED talks: The official TED guide to public speaking. London: Nicholas Brealey Publishing.

Baker, P. \& Ellege, S. (2011). Key Terms in Discourse Analysis. London: Continuum International Publishing Group.

Bauman, R. (2004). A World of Others' Words: Cross-Cultural Perspectives on Intertextuality. Malden, MA: Blackwell.

Baxter, J. (2010). Discourse-analytic approaches to text and talk. In L. Litosseliti (Ed.), Research Methods in Linguistics (pp. 117-137). London: Continuum.

Briggs, C. L., \& Bauman, R. (1992). Genre, intertextuality, and social power. Journal of Linguistic Anthropology, 2(2), 131-172. Retrieved from https://s3.amazonaws.com/academia.edu.docu ments/36870555/Briggs_Bauman 92.pdf?resp onse-content-

disposition=inline \%3B\%20filename\%3DGenr e Intertextuality and Social Power.pdf\&XAmz-Algorithm=AWS4-HMAC-SHA256\&XAmz-

Credential=ASIATUSBJ6BADE34GYUM\%2 F20200331\%2Fus-east-

1\%2Fs3\%2Faws4_request\&X-Amz-

Date $=20200331 \mathrm{~T} 094935 Z \& X-A m z-$

Expires $=3600 \& X-A m z-S e c u r i t y-$

Token=IQoJb3JpZ2luX2VjEAkaCXVzLWVh c3QtMSJHMEUCIQDYG4ysbXpHvXqcwoN zCXZuu4s\%2Bp9jF9xC6DNsrurtUcgIgbqZrK I\%2Bz7UTuKsHM7F\%2Ba94IoHkLS8g5CT F7BlVFWXxIqtAMIEhAAGgwyNTAzMTg4 MTEyMDAiDDFuJwVKxkX94Jc\%2B6CqR A07Lm5UG96P2TQvCaCMvUzoTHpJ17z71Z IWPz6V0LZaGZJs4CIhBpwQYjSwtQXizsF M6Amt9wZNGfWnApsdMY4R\%2FSQH48Y r6bQn55TrKDgTAJbU3UIBjIaWiJFAk6Wt0h Q\%2B9vyLcfS30eSQTUdXuzRp1WAMsCdd 9kK\%2FPp45V5z0rOZJoSwlitby0AzSVCuB \%2FbCw3SRN\%2FWTFOUXxsklYq\%2FAw ZFhtrcMJ9QZy\%2FvDxlOwvq3UO0Dh8kR4 pdsBLGLbA8bVnBov3QFYINqks7QRggwd w\%2BZsCK4C4yNvlP4lBkNV4IWbsiDQzk6 083oaqTi\%2BcJIeiTnZrQjhdeQrlLrORhR9T3 CLCcF\%2BSLbWjAljfdcwKoP8a3ffsP6TM7 5vFc9YKCjMfS5Kys7eFSA4yNxLiKWQeQ8 gEqBaSUOfQCnsZBbOohuuysB9P31PreD2V \%2B0x2J\%2FbygXmK1ZpSQ7g\%2BycLjO0 zEMbd03\%2F8vrwodrGFxK0UFnIEoBPJEw XH8cyBgmuz0yohejvikC5xuc9FA4A4HNPfE 5MJWDjPQFOusBh8DinNvxONx4EuivDGQ SdCwFwm89gTLdjgyMebOr3c8jQLHfLeAp YxCFo9bbq2a7rR12yXIWLs3yW1xRjWZtm QqjPL6GZEwC3REs3uF1ETHv31c3GiOD\% 2FPLdN\%2BR5rKfqksb9CQkXsrZRqVwEM
KdSk\%2F\%2F0AswGgJova0c97dhF6mrbsAr 8KkDf0dr18hSdA6B\%2F43DqvHJ5CNnuma vDda3\%2BeEb0\%2FLRpp8ueiT53LisLIDbxv 25ZPrb9f10q5CBz2Mm\%2FCwFjvLRE8gTL 4qxS\%2F62ZWKIlm4Z2WjqaHRFJGViP4O Y9r7qbXJqO2REKGA\%3D\%3D\&X-Amz-

SignedHeaders $=$ host\&X-Amz-

$\underline{\text { Signature }=494 \mathrm{df} 27 \mathrm{c} 5064 \mathrm{be} 13904790 \mathrm{bc} 65570}$ 751be0e74e1e9449dd980734d52825a4620 [Accessed: 17 June 2019].

Carstens, W. A. M. (1999). Text linguistics: Relevant linguistics? In I. Biermann \& A. Combrink (Eds.), Poetics, linguistics and history: Discourses of war and conflict (pp. 588-595). South Africa: Oxford Text Archive. Retrieved from:

https://www.pala.ac.uk/uploads/2/5/1/0/25105 678/carstens.pdf

De Beaugrande, R. \& Dressler, W. (1981). Introduction to Text Linguistics. London: Longman.

Fairclough, N. (1989). Language and Power. Essex: Longman.

Fairclough, N. (1992). Intertextuality in critical discourse analysis. Linguistics and education, 4(3-4), 269-293.

Fairclough, N. (1995b). Media Discourse. London: Arnold.

French, J. R. \& Ravem, B. (1959) The bases of social power. In J. M. Shafritz \& J. S. Ott (Eds.), Classics of Organization Theory, $5^{\text {th }}$ ed., pp. 319-328. Orlando, Fl.: Harcourt College Publishers.

Gee, J. P. (2011). An Introduction to Discourse Analysis: Theory and Method (3 ${ }^{\text {rd }}$ ed.). New York: Routledge.

Gee, J. P. (2014a). An Introduction to Discourse Analysis: Theory and Method (4th ed.). New York: Routledge.

Gee, J. P. (2014b). How to Do a Discourse Analysis: A Toolkit ( $2^{\text {nd }}$ ed.). New York: Routledge.

Gordon, C. (2009). Making meaning, creating family: Intertextuality and framing in family interaction. Oxford: Oxford University Press.

Halliday, M. A. K. \& Hasan, R. (1976). Cohesion in English. London: Longman.

Keep, C., McLaughlin, T., \& Parmar, R. (2000). Intertextuality. Retrieved from http://www2.iath.virginia.edu/elab/hfl0278.ht ml [Accessed: 13 November 2018].

Ludewig, J. (2017). TED Talks as an emergent genre. CLCWEB-Comparative Literature and Culture, 19(1), 1-9. Retrieved from https://dspace.allegheny.edu/bitstream/handle/ 10456/42646/Ludewig_2017_CLCWeb_TED \%20Talks.pdf?sequence $=1 \&$ is Allowed $=\mathrm{y}$ [Accessed: 6 September 2018].

McHoul, A. \& Grace, W. (2002). A Foucault primer: Discourse, power, and the subject. London: Routledge. 
Quirk, R., Greenbaum, S., Leech, G., \& Svartvik, J. (1985). A comprehensive grammar of the English language. London: Longman Group Limited.

Robinson, K. (2006, Feb.). Do schools kill creativity? Retrieved from https://www.ted.com/talks/ken_robinson_says _schools_kill_creativity/upnext?referrer $=$ playlistthe_most_popular_talks_of_all [Accessed: 9 December 2018].

Taher, M. D. (2016). Implicitness and intertextuality in media discourse: A Pragmatic-discourse study (MA thesis, University of Sulaimani, Sulaimani, Kurdistan, Iraq).

TED. (n.d.a). Conferences. Retrieved from https://www.ted.com/about/conferences [Accessed: 12 February 2019].

TED. (n.d.b). Our organization. Retrieved from: https://www.ted.com/about/our-organization [Accessed: 12 February 2019].

TED. (n.d.c). TED science standards. Retrieved from: $\quad$ https://www.ted.com/about/ourorganization/our-policies-terms/ted-sciencestandards [Accessed: 12 February 2019].

Tenorio, E. H. (2011). Critical discourse analysis, an overview. Nordic Journal of English Studies, 10(1), 183-210. Retrieved from http://ub016045.ub.gu.se/ojs/index.php/njes/ar ticle/viewFile/658/609 [Accessed: 6 September 2018].

Theunissen, G. (2014). Analysis of the visual channel of communication in a corpus of TED Talks presentations. (Master's thesis, University of Ghent, Ghent, Belgium). Retrieved from https://lib.ugent.be/fulltxt/RUG01/002/162/18 5/RUG01-002162185_2014_0001_AC.pdf [Accessed: 6 September 2018].

Trask, R. L. \& Stockwell, P. (2007). Language and Linguistics: The key concepts ( $2^{\text {nd }}$ ed.). New York: Routledge.

Van Dijk, T. A. (2008). Discourse and Power. London: Palgrave Macmillan.

Wang, W. (2006). Newspaper commentaries on terrorism in China and Australia: A contrastive genre study (Doctoral thesis, University of Sydney, Sydney, Astralia). Retrieved from https://ses.library.usyd.edu.au/bitstream/2123/ 1701/5/05chapter4.pdf [Accessed: 9 June 2019].

Wodak, R. (2001). What CDA is about: A summary of its history, important concepts and its development. In R. Wodak \& M. Meyer (Eds.), Methods of Critical Discourse Analysis, pp. 1-13. London: Sage Publications Ltd. 